\title{
The Impact of the German Child Benefit on Child Well-Being
}

\author{
Christian Raschke*
}

March 25, 2012

\begin{abstract}
The German Child Benefit ("Kindergeld") is paid to legal guardians of children as a cash benefit in order to satisfy the constitutional requirement that children's minimum existence not be taxed. This study employs exogenous variation in the amount of child benefit received by households in the German Socio-Economic Panel to investigate the extent to which these various changes in Child Benefit have translated into an improvement in the well-being of the children. Although the data set does not contain information regarding direct measures of child well-being, it allows for an investigation of household expenditures and behaviors that in return impact the well-being of childen. I estimate the impact of changes in the child benefit on the probability of owning a home, the size of the home, the probability of owning a car, food expenditures, as well as the probability of smoking and alcohol consumption behavior. I use household fixed effects specifications and control for time-varying covariates such as other types of household income, household composition, number of children in the household in order to cleanly identify the effect of child benefit income. The paper informs policymakers regarding the efficacy and effectiveness of the child benefit.
\end{abstract}

*Department of Economics, Louisiana State University, 2128 P. Taylor, Baton Rouge, LA 70803, USA. 


\section{Introduction}

The parents of children in Germany receive a monthly child benefit ("Kindergeld") for every child. This benefit is not means tested and all German and EU citizens living in Germany qualify for it. ${ }^{1}$ The Child Benefit is at the core of all family support policies in Germany and the Federal Constitutional Court has confirmed that it is intended to ensure that children's needs in terms of nutrition, housing, clothing, personal hygiene, and heating are met (Bundesverfassungsgericht, 1998). Since the benefit is not provided in-kind but rather as a cash transfer to the parents, how much of the additional income is actually used to improve the welfare of children remains an open empirical question.

While there exists some literature investigating the impact of child benefit systems in different European countries and Canada, this study is the first to investigate the impact of child benefit income on various dimensions of household expenditures and parental behavior in Germany. More importantly, this paper contributes to the literature by cleanly identifying the effect of the child benefit: I use a panel data set of households and exploit exogenous intra-household variation in the amount of the benefit to isolate its effect on the outcomes of interest. Using within-household variation of child benefit income in a panel of households and controlling for various timevarying household characteristics overcomes the identification problem of separating the effect of a child benefit from the effects of differences in the number of children, ages of children, and other confounding factors noted in the previous literature (Edmonds, 2002).

Standard economic theory of consumer choice predicts that the source of any additional household income is irrelevant in determining how that additional income is spent (Becker, 1981). Families maximize a joint utility function and a cash transfer shifts out the family budget constraint. The change in expenditures resulting from the shift in the budget con-

\footnotetext{
${ }^{1}$ Parents who are German citizens but live abroad may be eligible if they earn income that is fully taxable in Germany. Non-EU citizens may be eligible for child benefit depending on their immigration status. The details of the eligibility rules can be found in $\S 62$ Einkommensteuergesetz (EStG) and $\S 1$ Bundeskindergeldgesetz (BKGG).
} 
straint does not depend on the source of the additional income and increases in the child benefit will result in the same Engel curves as would increases in other types of household income. There are many reasons why this prediction may not hold (see for example Browning et al., 1994; Lundberg and Pollack, 1993; Schady and Rosero, 2008) and studies investigating child benefits in different countries, have confirmed that investigating households' responses to changes in the child benefit is a worthwhile exercise.

For example, Kooreman (2000) used repeated cross sections of Dutch consumer expenditure surveys to investigate the effect of the Dutch child benefit system on parents' spending behavior. He found that the effect of an increase in child benefit income on child clothing expenditures is larger than the effect of an increase in income from other sources on child clothing expenditures for households with only one child. Kooreman suggested that this may be caused by a labeling effect, where parents keep "mental accounts" as suggested in Thaler (1990). However, this labeling effect vanished in households with more than one child: larger families did not distinguish between child benefit income and income from other sources. In a related study, Edmonds (2002) used cross-sectional household data of the Slovenian child benefit program from 1993 to investigate the impact of the child benefit on household expenditures for food, tobacco, alcohol, and clothing. He was unable to find a statistically significant impact of child benefit payments on any of the above household expenditures.

Most recently, Blow et al. (2012) examined the United Kingdom's Child Benefit program and found that up to half of a marginal dollar of an increases in the UK child benefit is spent on alcohol. Blow et al. (2012) studied the time period of 1980-2000 and relied on variation in the real child benefit due to the fact that the government imperfectly accounted for inflation when adjusting the nominal child benefit, and that the amount of child benefit received for the first child increased considerably on two occasions due to a policy change. Changes in the UK's Child Benefit policies have also been used by Lundberg et al. (1997) to show that expenditure patterns are different when the child benefit is paid to the mother, compared to when it is paid to the father. They show that expenditures on women's and child clothing 
increased when a reform of the UK's system transferred the payout of the benefit from the head of household to the mother.

Given these sharply different results, this paper adds to the evidence on the effects of child benefit income. Using a data from the German Socio-Economic Panel from 1996 to 2009, I find that the probability of home ownership increases in the child benefit, as does the probability that the family has access to a garden. For those households who rent their home, the size of the residence increases. These effects are statistically significant, but their magnitude is small. There is no significant impact of child benefit on housing variable for those who already own their home. Moreover, I find that for higher income households the probability of owning a car increases in the child benefit. Again the effect is statistically significant but small. The largest significant effect of child benefit income is on food expenditures and in this case the effect is larger for low income families compared to higher income families. The increase in the child benefit over the sample period used in this paper has increased per capita food expenditures by about $€ 15.19$ per month for low income households, and by about €8.96 for higher income households.

At the individual level I find that an increase in child benefit increases the probability of smoking of the parent, but that there is no significant effect on drinking behavior. Finally, I find that increases in the child benefit negatively affect the labor supply of men: Men work about 25 minutes less per week in response to the increase in child benefit that took place between 1996 and 2009 .

\section{Background of the Child Benefit Program in Germany}

The basic idea of the child benefit is as follows: ${ }^{2}$ The living wage of an individual or couple is not subject to income tax and only income that exceeds that living wage ("Grundfreibetrag")

\footnotetext{
${ }^{2}$ In this section I describe the current child benefit system (1996-present). See Ruhl (1994) for an interesting historical perspective on different approaches to family policy in Germany starting with the early 1900s.
} 
is taxable. ${ }^{3}$ Households with children are eligible for an additional tax deduction for each child ("Kinderfreibetrag"), but this additional deduction is not considered when calculating tax withholdings. Instead, families with children receive a monthly child benefit in cash. The cash benefit is strictly a function of the number of children; household income or other considerations are irrelevant. ${ }^{4}$ This means that a household with two children pays the same amount of income tax as a childless but otherwise identical household with identical income, yet the household with children receives the cash child benefit while the childless household does not.

At the end of the year, the Tax Office calculates the total yearly amount of cash child benefit received by the household, and it also calculates the potential tax savings if the child deduction would have been taken instead. For most households the total yearly cash child benefit they received throughout the year exceeds the tax savings that would have resulted from claiming the child deduction. In this case the household keeps the excess amount as a transfer payment ("Förderanteil"). For households with very high income, the tax savings from taking the child deduction exceeds the total yearly child benefit. In this case, the houshold claims the deduction and pays back any child benefit received. ${ }^{5}$ The Tax Office determines ex officio whether the child benefit or the child deduction results in larger savings for the household and therefore this choice is not subject to errors or by the filing household.

Due to changes in the tax schedule and changes in the amount of the allowed decuction, the taxable household income threshold beyond which taking the tax deduction provides a larger benefit than taking the cash payment varies slightly over time. In 2009, there were

\footnotetext{
${ }^{3}$ This is equivalent to a "personal exemption" in the U.S. income tax system.

${ }^{4}$ All children are generally eligible until they turn 18 years old. Thereafter, the parents may still receive child benefit for the child until the child turns 25 if certain conditions regarding employment status and earnings of the child are met. For instance, a family may continue to receive child benefit for a child older than 18 years if the child still attends school or university. The precise conditions to be able to receive the benefit beyond the 18th birthday of the child changed over time and are not be considered in this paper.

${ }^{5}$ The current system of receiving a large cash benefit, or a tax deduction has been in place since 1996. Prior to 1996, households received both a tax credit and a (much smaller) cash benefit payment. Due to this change in policy, I restrict my attention to 1996 and beyond. Indeed, previous studies have used changes in the child benefit law as an exogenous source of income variation. For example, Tamm (2008) used the 1996 change in the law as a "natural experiment" that increased income for households with children. He used this natural experiment to determine that income is not causally related to school choice in Germany.
} 
17.7 million children eligible for child benefit in Germany. Only $11.8 \%$ of those children lived in households with sufficiently high household income to be considered for the tax deduction instead of the cash benefit. In monetary terms, direct state expenditures due to the child benefit and the child deduction were $€ 38.5$ billion in 2009 (about 1.6\% of GNI), $€ 36.9$ billion of which were for the cash benefit and the remaining 1.7 billion for the tax deduction (Bundesministerium der Finanzen, 2010).

Taxable income is not directly observed in the data and is difficult to accurately impute. Therefore, I use only the cash amount of child benefit that is paid out to everyone throughout the year. Ignoring the possibility of a larger benefit when filing their tax return for households with higher income means that the amount of child benefit can be considered a lower bound. Given that -as outlined in the previous paragraph- the majority of households receive the cash benefit, I do not expect that using the lower bound of benefit received will have an impact on the results presented below. However, I do estimate separate specifications for those households that are considered to be at-risk for poverty because the child benefit is a larger share of their overall household income.

Contrary to the UK's benefit studied in Blow et al. (2012), where during the considered time frame the primary real variation between years came from imperfect inflationadjustment of the nominal benefit amount, changes in the German child benefit amounts are considerably larger and the increases in the amount have exceeded the devaluation due to inflation.

\section{Empirical Strategy and Data}

I estimate a number of household level equations explaining choices regarding housing, the probability of having a car in the household, and per person food expenditures. These outcomes do not capture expenditures that are directly assignable to children, but since the child benefit is intended to support - among other things- housing and nutrition of children, 
the results will allow an important insight into whether the child benefit is spent according to the intentions of the policy maker. Moreover, I estimate several individual level equations to investigate the impact of child benefit on the probability of smoking, drinking, and the impact on labor supply of the father. ${ }^{6}$

For the household level specifications, I assume that the outcome of interest, $k$, of household $j$ during time $t$ is described by the reduced form equation

$$
\text { Outcome }_{j t k}=f_{k}\left(Y_{j t} ; \mathbf{Z}_{j t}\right)
$$

where $Y_{j t}$ is the real net monthly household income of household $j$ during year $t$ and $\mathbf{Z}_{j t}$ contains other exogenous time-varying characteristics of the household. If real monthly net household income, $Y_{j t}$ consists of the child benefit, $y_{j t}$, and income from other sources, $x_{j t}$, then

$$
\text { Outcome }_{j t k}=f_{k}\left(y_{j t}, x_{j t} ; \mathbf{Z}_{j t}\right)
$$

Following Kooreman (2000), Edmonds (2002), and Blow et al. (2012) I assume that $f_{k}(\cdot)$ is linear, and that $y_{j t}$ and $x_{j t}$ are additively separable.

The empirical specification takes the following fixed-effects form:

$$
\text { Outcome }_{j t k}=\alpha_{k} y_{j t}+\beta_{k} x_{j t}+\mathbf{Z}_{j t} \gamma_{k}+\mu_{j k}+\nu_{s k}+\tau_{s t k}+\varepsilon_{j t k}
$$

where $\mathbf{Z}_{j t}$ contains the number of children in the household and any other family attributes. Since the child benefit is a strict function of the number of children, controlling for the number of children in the household is essential to isolate the effect of the child benefit from any other effect of the number of children in the household. $\mu_{j}$ is a vector of household fixed effects so that the effect of child benefit can be identified from variation in the child benefit

\footnotetext{
${ }^{6}$ I do not consider labor supply of the mother because of generous paid maternity leave regulations as well as laws that prohibit mothers of newborn children to be employed under any circumstance ("Mutterschutz"). These factors complicate labor supply decisions of the mother and make it very difficult to identify the effect of child benefit income.
} 
within the households over time. $\nu_{s}$ is a set of indicators for the state of residence of the household to account for systematic differences in behavior accross regional areas, and $\tau_{s t}$ represents the set of region specific time trends to capture systematic variation over time in each region. $\varepsilon_{j t k}$ is an idiosyncratic error term.

When the outcome of interest is observed at the individual level instead of the household level, equation (3) becomes

$$
\text { Outcome }_{i t k}=\alpha_{k} y_{j t}+\beta_{k} x_{j t}+\mathbf{Z}_{i j t} \gamma_{k}+\mu_{i k}+\nu_{s k}+\tau_{s t k}+\varepsilon_{i t k}
$$

where the subscript $i$ denotes the individual. Note that in this individual-level fixed effects specification the income variables $x_{j t}$ and $y_{j t}$ are still observed at the household level, and $\mathbf{Z}_{i j t}$ now also contains time-varying exogenous characteristics of the individual in addition to the household level characteristics used in the specification of equation (3).

I use data from the German Socio-Economic Panel (SOEP) to estimate specifications according to equation (3) and (4). The SOEP is a longitudinal data set that has been collecting data since 1984, with multiple refreshment samples (in 1993, 1998, 2000, and 2006) to counter sample attrition. ${ }^{7}$ Among many other detailed household characteristics and individual characteristics of each household member, the data also contain information regarding the amount of child benefit received, as well as the number of children in the household (see Wagner et al., 2007). ${ }^{8}$

In 1996 there was a change in the way that the child benefit is administered. Prior to 1996, households received both a tax credit and a small cash benefit. From 1996 onward, the child benefit system has been administered according to the description in Section 2. To avoid complications due to the different child benefit policies before 1996, I restrict my

\footnotetext{
${ }^{7}$ In addition, in 2002 there was a separate sample taken that targeted high income households. Due to the fact that the tax savings due to a tax credit may be larger than the sum of the monthly cash child benefit payments for this group, I exclude the 2002 high income sample from my estimations. My results are not sensitive to omitting or including this sample in the estimations.

${ }^{8}$ I use the official monthly amounts of child benefit for which households are eligible to correct for measurement error in the reported child benefit variable. Respondents are much less likely to committ an error when counting their children compared to remembering the precise amount of child benefit they receive.
} 
attention to the years 1996-2009. After further restricting the sample to include only those households with children, this leaves me with 45,359 household-year observations.

Figure 1 shows that that there is variation in the real amount of child benefit received over time, conditional on the number of children. For an example, a family with two children would receive $€ 231.03$ per month in 1996. By 2009, the amount of the child benefit increased by about $33 \%$ to $€ 306.54$ per month for exactly the same two children. Note that these values are in real 2005 Euros. Note also, that in real terms child benefit is not strictly increasing over time. The amount of real child benefit was actually highest in 2002 .

It is important to emphasize that (conditional on the number of children) the change in child benefit is exogenous and does not depend on any other family characteristics. Issues regarding the take-up of social assistance may be a concern if, for instance, a welfare stigma discourages households to apply for support for which they may be eligible (Moffitt, 1983). In the context of the German child benefit these issues are not a concern. Due to the universal eligibility of children the child benefit is not considered a social assistance in the same sense that welfare programs are considered social assistance, and it is not associated with welfare stigma (Frick and Groh-Samberg, 2007).

The first outcome of interest is related to housing. In particular, I estimate the impact of the child benefit on the probability that the household owns or rents their residence, as well as on the size of the residence. Questions about the residence of the household are asked in every wave of the survey so that changes in the housing conditions of households can be tracked very precisely. There are two margins along which the child benefit may impact the consumption of housing services. First, a household may choose to either rent or own a home. Second, a household may "move up" to a larger or otherwise improved home. For those households that currently rent their home, an increase in income could result in changes along either margin. The household may decide to pursue home ownership, or they may choose to rent a larger residence. On the other hand, home owners are very unlikely to go back to renting a home due to changes in child benefit income. Moreover, since selling a 
home is more costly and time consuming than terminating a lease, it is also less likely that home owners will purchase a larger home due to the change in child benefit income. Since there may be systematic differences in how renters react to increased income compared to owners, I estimate separate regressions for renters and owners.

Investigating whether a change in the child benefit impacts the probability of owning a car allows an insight into whether child benefit income is also used to purchase large ticket items. While a car is not a commodity that is assignable to the child directly, there are certainly benefits to the child from having a car available in the household. Questions regarding whether a car is available in the household are asked in 1996 and in every year between 2000 and 2008. Data on total expenditures on food are available for the years 1998, 2000, 2001, 2003, 2005, and 2007. Using information of the number of household member, I construct a measure of per person household expenditures on food.

At the individual level, I investigate whether the child benefit has any impact on the probability of being a smoker by using questions regarding tobacco consumption asked during 1999, 2001, 2002, 2004, 2006, and 2008. It is certainly not in the interest of the policy maker to support parents' smoking habit. This is especially true because the health effects of second hand smoke may have a direct negative impact on the child's wellbeing. In addition to smoking, I explore the relationship between child benefit and the consumption of alcohol.

The child benefit is a much larger share of total household income for low income households and since the family-support component ("Förderanteil") of the benefit is particularly high for those families, I estimate some specifications separately for low and high income households. In the European Union, a household is considered to be living in relative poverty if household income is below $60 \%$ of the national median of comparable households, after social transfers. I define a household to be low-income if the mean real net monthly household income is less than $60 \%$ of the median of the distribution of the household-means of real income in the sample. Since my data set contains a panel of households, using $60 \%$ of the mean of household income over time smoothes over transitory income shocks so that 
they are not considered in determining the sample, while staying true to the spirit of the definition. None of the results below are very sensitive to the choice of the income cutoff.

\section{Results and Discussion}

\subsection{Household Level Results}

The first set of results pertain to the housing conditions of the family. I estimate equation 3 , where the outcomes are the probability that the family rents or owns their dwelling, the size of the dwelling measured in square meters, and the size of the dwelling measured in the number of rooms that are larger than 6 square meters. I exclude households that live in public subsidized housing from the estimations. Column 1 of Table 3 shows that the probability of renting (versus owning) a home decreases by about 0.07 percentage points for a one percent increase in the amount of child benefit. Moreover, the results presented in columns 2 and 3 of Table 3 show that a one percent increase in child benefit is associated with a $0.057 \%$ larger apartment when size is measured in square meters, as well as an $0.064 \%$ larger apartment when measuring size by using the number of rooms in the residence. While these results are statistically sigificantly different from zero, the magnitude is small. The mean size of the residences in our sample is about 110 square meters and for a household with two children the 33\% increase in child benefit experienced from 1996-2009 translates into an average increase in size of about 2 square meters (about 21.5 square feet). Households are a statistically significant 0.068 percentage points more likely to have access to a garden at their residence as child benefit income increases by one percent (column 4).

The second row in Table 3 presents the income elasticities with respect to the outcomes. Since child benefit income is completely fungible, we should not expect a difference of the coefficients on child benefit income and other household income. As expected, an F test of the hypothesis that the two coefficients are equal fails to reject equality for the equation explaining the probability of renting, as well as the equations explaining the size of homes. 
However, column 4 shows that the impact of a change in child benefit income on the probability of having access to a garden is statistically significantly larger than the impact of other household income on the probability of having access to a garden. The F test of equality of the coefficients rejects equality with a p-value of 0.0747 .

Renters are likely to react differently to increases in child benefit income compared to home owners because switching rented apartments or houses is associated with much lower transaction costs compared to selling or purchasing a home. Table 4 displays results of estimating equation (3) considering only those households who rent their home. Columns 1 and 2 show that there is no significant impact on the amount of rent per square meter, or the amount of utility payments per square meter per month. Rent per square meter can be interpreted as a measure of the quality of the home. While the impact of other household income on the quality of the residence is positive and significant, the effect of the child benefit is statistically indistinguishable from zero. As expected, neither child benefit income or other income have any effect on monthly utility expenses for heating and warm water, etc per square meter.

With respect to the measures of size of residences, columns 3 and 4 of Table 4 show that the impact of child benefit income is positive and significant for renters. The coefficients of home size measured in square meters and the number of rooms are about 0.08 and 0.11 , respectively. Therefore, the income elasticity with respect to the size of a household's residence is larger in the subsample of renters compared to the overall sample. Table 4 further shows that the probability of having access to a garden and the probability of evaluating the size of one's dwelling as too small are not impacted by child benefit income (columns 5 and 6). Investigating any labelling effect that may be associated with child benefit income results in a significantly different coefficient of child benefit income and other sources of income only for the equation explaining the size of the home as measured by the number of rooms. In this equation the impact of a change in child benefit income is significantly larger than the effect of a change in other types of income. 
Results for households that own their residence are presented in Table 5. I estimate again the impact of the child benefit amount on the size of the residence and whether the residence comes with access to a garden. Home ownership is not always associated with regularly recurring payments. A household may be paying a mortgage, but they may also have inherited the home, or paid off the home already in the past. Therefore, I do not have an equivalent to "rent" available for owners. Utility expenditures (heating and warm water, etc) are only available for renters in the data. For both measures of size the coefficient of interest is statistically insignificant. This is, not surprising because home owners are likely to require a much larger increase in income compared to renters before they would consider leaving their home. Interestingly, the coefficient of the child benefit in the equation explaining the probability of having access to a garden is statistically significant, though only marginally.

The fact that the impact of the amount of child benefit on having a yard is highly statistically significant and largest in the overall sample, but indistinguishable from zero when estimating the specification for renters and only marginally significant when estimating the specification for owners separately suggests that moving from renting to owning is the mechanism for obtaining a garden. This is corroborated by the negative and significant coefficients of the controls for owning versus renting in the overall regressions presented in Table 3.

Table 6 shows results of the impact of the child benefit on the probability of a car being available in the household. The first column shows that the probability of owning a car increases by 0.027 percentage points as the child benefit increases by 1 percent. This result is statistically significant at the 5 percent level, yet the magnitude of the impact is very small. Since a large number of households already own a car (91\% of the observations), I estimate separate specifications for families with low average household income. Columns 2 and 3 of Table 6 show that the point estimate of the impact of the child benefit on the probability of owning a car is much larger for low income households. However, the point estimate is statistically insignificant for the low income sample as well as the higher income subsample. 
The impact of other income on the probability of owning a car is highly statistically significant regardless of the subsample. Moreover, despite the imprecise estimation of the elasticity for the high income sample, an F-test rejects the hypothesis that the coefficients on child benefit income and other income are equal with a p-value of 0.0832. In this case, however, the coefficient on child benefit is significantly smaller than the coefficient on other types of income. If this should be interpreted as evidence for a labeling effect, then parents are less likely to spend child benefit income on a car than they are other types of income.

Next, I present results of estimations that investigate the impact of child benefit on monthly food expenditure per person in the household. Table 7 shows that the child benefit income elasticity with respect to household per person monthly food expenditure is about 0.19. Households spend about $€ 149.15$ per person per month on food on average and therefore a family with two children would have increased food expenditures by about $€ 9.35$ for each household member. For the entire family of 4, this translates into increases in food expenditure by $€ 37.40$ per month.

For low income households, the child benefit income elasticity on per person food expenditures is a much larger 0.39 compared to the higher income household's elasticity of 0.17 . Low income households spend less on food (€122.71 per person) compared to higher income households (€156.08 per person). The increase in child benefit for a family with two children over our sample period is associated with a $€ 15.90$ increase in low income households, compared to $€ 8.67$ in higher income households. If per person monthly food expenditure are a proxy for nutritional quality, then the child benefit improves household well-being, especially for low income households.

\subsection{Individual Level Results}

Next, I turn my attention to individual level outcomes. As described above, I use a panel of individuals for these estimations and I include individual level fixed effects. The child benefit income, number of children, as well as other household characteristics are still observed at 
the household level. In order to ensure that the sample used in the estimations does not include any children themselves, I restrict my sample to individuals who are at least 25 years old.

First, Table 8 shows that the probability of being a smoker increases in the amount of child benefit received. As child benefit income increases by one percent, the probability of being a smoker increases by about 0.068 percentage points. This effect is statistically significant and larger for males (0.083) compared to females (0.059) in the sample. The impact is larger yet for immigrants: a one percent increase in child benefit income increases the probability of smoking by 0.13 percentage points. Interestingly, the coefficient of other household income is insignificant in all regressions and the test for equality of the coefficients rejects in all cases except the specification that uses only female respondents. Child benefit income does not seem to have any effect on smoking intensity. Table 9 shows that conditional on being a smoker, child benefit income does not have a statistically significant effect on the number of cigarettes smoked. This is the case for the entire sample, as well as for subsamples by gender or immigrant status.

When distinguishing between low income and higher income households, I find that there is no effect of child benefit income on smoking for the low income subsample (Table 10). However, the coefficients for the higher income subsample are still positive and highly statistically significant. For the higher income subsample, a one percent increase in child benefit income increases the probability of being a smoker by almost a tenth of a percentage point. Note, however, that the baseline probability of being a smoker is still much higher for individuals living in low income households. about $54 \%$ of individuals living in low income households were smokers, compared to only $36 \%$ of individuals living in higher income households.

Table 11 presents results on drinking behavior. The dummy variable is coded to 1 if the individual indicated to frequently consumer either beer, wine, liquor, or mixed drinks and zero otherwise. In addition to household level controls, I also include the sex and level of 
education of the individual, as well as a quadratic term in age. I do not find a statistically significant impact of child benefit income on the probability of drinking alcohol frequently. Blow et al. (2012) found that a large proportion of unexpexted increases in child benefit income in the UK were spent on alcohol. While I am not able to identify expenditures on alcohol, I am still unable to find a significant impact on drinking behavior in response to changes in child benefit income. Note, however that respondents to the SOEP were asked about their drinking behavior only twice: in 2006 and 2008. During this time there was no change in nominal child benefit and the only identifying variation in child benefit comes from the fact that inflation decreased real child benefit between 2006 and 2008. Due to these data limitations results from the drinking behavior regressions should be taken with caution.

Finally, I investigate whether child benefit income has an impact on labor supply. I concentrate on the labor supply of men because there are legal restrictions imposed on women after giving birth with respect to market work. Moreover, identifying the impact of a child benefit is difficult due to the possibility of paid maternity leave or similar policies designed to reduce the opportunity cost of staying at home to take care of young children. ${ }^{9}$ Table 12 presents the results of estimating the impact of child benefit income on the average number of hours worked per week. In addition to household characteristics and standard individual level controls, I include a regressor for tenure at the firm, as well as a variable indicating the number of years of full time work experience in all regressions. Moreover, I include an indicator for whether the individual is employed fulltime, part time, or or irregularly employed, as well as an indicator for being a civil servant.

Column 1 of Table 12 shows that as child benefit income increases, the number of actual hours worked per week decreases. A one percent increase in child benefit is associated with a $0.03 \%$ decrease in hours worked per week. At an average work week of about 44 hours, the 33\% increase in child benefit payments between 1996 and 2009 for a family with two

\footnotetext{
${ }^{9}$ Technically, it is also possible for males to receive paid leave after the birth of a child into their family. However, many more women make use of such opportunities compared to men and therefore I concentrate on men.
} 
children therefore decrease the length of the workweek by about 25 minutes. Columns 2 and 3 show that the impact on the number of hours per week specified in the individual's labor contract is smaller than the impact on the number of over time hours worked. A one percent increase in child benefit payments decreases contractual hours by $0.01 \%$, while over time hours decrease by about $0.14 \%$.

\section{Conclusion}

This paper investigated the effect of exogenous changes in child benefit income in Germany on various dimensions of household expenditures and behaviors. Using panel data from the German Socio-Economic Panel, I identify the effect of changes in the child benefit on households' probability of homeownership, the size of their residence, the probability of having acces to a garden, the probability of having a car, as well as total weekly food expenditures. At the individual level, I investigate the impact of child benefit income on smoking and drinking behavior, as well as its impact on labor supply of the father. Since I use panel data and include household or individual fixed effects in all estimations and control for for the number of children, household composition, and other household and individual time varying characteristics, it is possible to very cleanly identify the effect of child benefit income.

I find that there is a statistically significant impact of child benefit income on the probability of owning a home, as well as on the probability of having access to a garden. The magnitude of the impact, however, is small. Among those households who rent their home, the size of the residence increases as well. For home owners, there is no significant effect of child benefit income on the size of homes. I find that for higher income households the probability of owning a car increases in the child benefit. Again the effect is statistically significant but small. The largest significant effect of child benefit income is on food expenditures. The increase in the child benefit over the sample period used in this paper has increased per 
capita food expenditures by about $€ 15.19$ per month for low income households, and by about $€ 8.96$ for higher income households.

At the individual level I find that an increase in child benefit increases the probability of smoking of the parent, but that there is no significant effect on drinking behavior. Finally, I find that increases in the child benefit negatively affect the labor supply of men: Men work about 25 minutes less per week in response to the increase in child benefit that took place between 1996 and 2009 .

Since it is the explicit intention of the policy maker to ensure the wellbeing of children in terms of nutrition and housing, my results show that the child benefit does indeed have the desired effect. The increase in food expenditures in response to increases in child benefit income is particularly large and if per capita food expenditure is interpreted as a proxy for nutritional quality, then the child benefit improves well-being of children especially in lower income households. Contrary to previous literature on child benefit systems from different countries, however, I find only limited evidence that parents treat child benefit income different from other sources of income. Except for few instances, I am unable to conclude that the impact of a change in child benefit income is statistically different from the impact of a change in other types of income.

I also find that increases in child benefit income are associated with an increased probability of smoking. This effect is observed in higher income households and is certainly not in the interest of the policy maker. The effect of child benefit income on smoking is statistically significanly larger than the impact of changes in other types of income on smoking. While it seems paradoxical that child benefit income causes smoking, other studies in different countries have also found that child benefit income is associated with bad health inputs in parents. For example, Blow et al. (2012) showed that unexpected increases in child benefit in Britain are mainly used for alcohol. The mechanism of this effect warrants further research.

Finally, I show that additional child benefit income is associated with decreased labor supply in the fathers of the children. For a family with two children, the exogenous changes 
in child benefit between 1996 and 2009 results in a reduced labor supply of about 25 minutes per week for men. 


\section{References}

Becker, G. S. (1981). A Treatise on the Family. Harvard University Press, Cambridge.

Blow, L., Walker, I., and Zhu, Y. (2012). Who benefits from child benefit. Economic Inquiry, $50(1): 153-170$.

Browning, M., Bourguignon, F., Chiappori, P., and Lechene, V. (1994). Incomesand Outcomes:A structural model of intrahousehold allocation. Journal of Political Economy, 102(6):1067-1096.

Bundesministerium der Finanzen (2010). Datensammlung zur steuerpolitik, ausgabe 2010. Technical report, Bundesministerium der Finanzen - Referat Öffentlichkeitsarbeit, Berlin.

Bundesverfassungsgericht (1998). BVerfG, 2 BvR 1057/91.

Edmonds, E. (2002). Reconsidering the labeling effect for child benefits: evidence from a transition economy. Economics Letters, 76(3):303-309.

Frick, J. R. and Groh-Samberg, O. (2007). To claim or not to claim: Estimating Non-TakeUp of social assistance in germany. Discussion Paper 734, DIW, Berlin.

Kooreman, P. (2000). The labeling effect of a child benefit system. American Economic Review, 90(3):571-583.

Lundberg, S. and Pollack, R. A. (1993). Separate spheres bargaining and the marriage market. Journal of Political Economy, 101(6):988-1010.

Lundberg, S. J., Pollack, R. A., and Wales, T. J. (1997). Do husbands and wives pool their resources? evidence from the united kingdom child benefit. The Journal of Human Resources, 32(3):463-480.

Moffitt, R. (1983). An economic model of welfare stigma. The American Economic Review, 73(5):1023-1035. 
Ruhl, K. (1994). Verordnete Unterordnung: Beruftstätige Frauen zwischen Wirtschaftswachstum und konservativer Ideologie in der Nachkriegszeit. R. Oldenbourg Verlag, München.

Schady, N. and Rosero, J. (2008). Are cash transfers made to women spent like other sources of income? Economics Letters, 101(3):246-248.

Tamm, M. (2008). Does money buy higher schooling? Economics of Education Review, $27(5): 536-545$.

Thaler, R. H. (1990). Anomalies: Saving, fungibility, and mental accounts. Journal of Economic Perspectives, 4(1):193-205.

Wagner, G. G., Frick, J. R., and Schupp, J. (2007). The german Socio-Economic panel study (SOEP) - scope, evolution and enhancements. Schmoller's Jahrbuch, 127(1):139-169. 


\section{Figures and Tables}

Figure 1: Child Benefit Amounts, 1996-2009 (Real 2005-€)

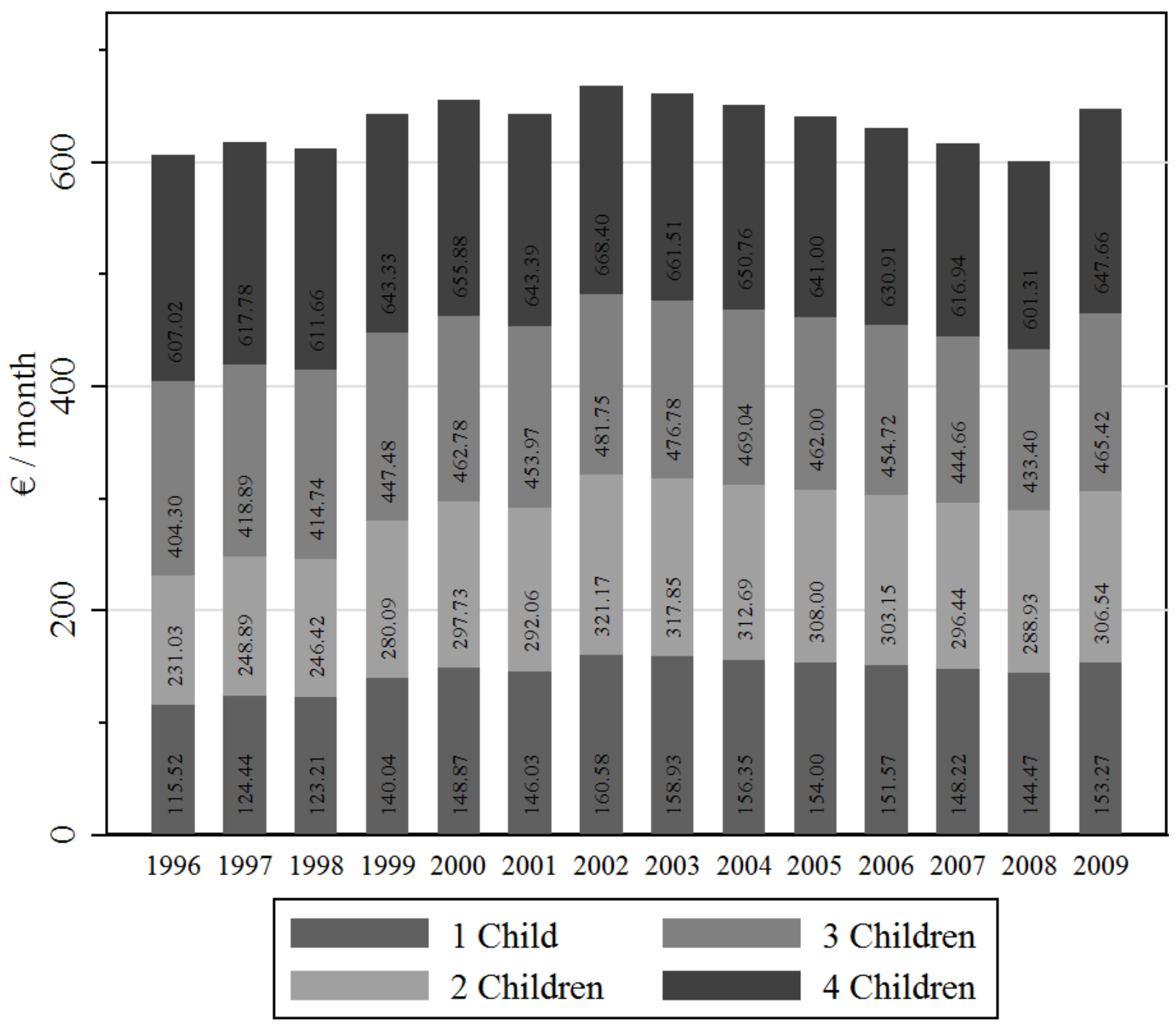

Note: Numbers inside the bars represent cumulative totals 
Table 1: Household Summary Statistics

\begin{tabular}{|c|c|c|c|c|}
\hline Variable & Description & Mean & Std. Dev & Obs \\
\hline Child Benefit & Real Child Benefit in $2005 € /$ month & 257.28 & 135.83 & 45,359 \\
\hline HH Income & $\begin{array}{l}\text { Real Net Houshold Income in } \\
2005 € / \text { month }\end{array}$ & $2,656.482$ & $1,420.82$ & 43,707 \\
\hline Number of Children & $\begin{array}{l}\text { Number of Children in Household for } \\
\text { which child benefit is received }\end{array}$ & 1.73 & 0.84 & 45,359 \\
\hline Renter & $\begin{array}{l}\text { Household rents or owns their residence } \\
\text { (Rent }=1 / \text { Own }=0)\end{array}$ & 0.4979 & 0.5000 & 45,358 \\
\hline Size $\left(m^{2}\right)$ & $\begin{array}{l}\text { Size of the residence measured in square } \\
\text { meters }\end{array}$ & 109.5 & 41.99 & 45,358 \\
\hline Size (Rooms) & $\begin{array}{l}\text { Size of the residence measured in the num- } \\
\text { ber of rooms larger than } 6 \text { square meters }\end{array}$ & 4.46 & 1.62 & 45,359 \\
\hline Yard & $\begin{array}{l}\text { Household's residence comes with access to } \\
\text { a garden }\end{array}$ & 0.6687 & 0.4707 & 44,708 \\
\hline Rent $/ m^{2}$ & $\begin{array}{l}\text { Rent per square meter in real } \\
2005 € / \text { month }\end{array}$ & 5.86 & 1.92 & 21,656 \\
\hline Utilities & $\begin{array}{l}\text { Heating, Hot water, etc cost per square } \\
\text { meter in real } 2005 € / \text { month }\end{array}$ & 1.94 & 0.68 & 21,656 \\
\hline Food Exp & $\begin{array}{l}\text { Total per capita monthly expenditures on } \\
\text { food in the household }\end{array}$ & 149.15 & 68.41 & 21,088 \\
\hline Has Car & Household has a personal car & 0.9142 & 0.2799 & 34,854 \\
\hline Single Parent & Single Parent & 0.1315 & 0.3379 & 45,359 \\
\hline Children age $<=16$ & $\begin{array}{l}\text { All children in the household are less than } \\
16 \text { years old }\end{array}$ & 0.6411 & 0.4796 & 44,315 \\
\hline $\begin{array}{l}\text { Children age }<=16 \\
\text { and }>16\end{array}$ & $\begin{array}{l}\text { Some children in the household are older } \\
\text { than } 16 \text {, some are younger than } 16\end{array}$ & 0.1599 & 0.3665 & 44,315 \\
\hline Children ages $>16$ & $\begin{array}{l}\text { All children in the household are older than } \\
16 \text { years }\end{array}$ & 0.1990 & 0.3170 & 44,315 \\
\hline Foreign & The head of household is an immigrant & 0.1133 & 0.3171 & 45,359 \\
\hline
\end{tabular}

Note: Net HH Income does not include the Child Benefit. Real Child Benefit and real net household income were calculated using the overall consumer price index. Rent and Utilities were deflated using the specific rent-and-utility price index. 
Table 2: Individual Level Summary Statistics

\begin{tabular}{|c|c|c|c|c|}
\hline Variable & Description & Mean & Std. Dev & Obs \\
\hline Education & Years of formal education & 12.27 & 2.72 & 87,282 \\
\hline Age & Age in Years & 41.31 & 8.92 & 88,848 \\
\hline Smoking & $\begin{array}{l}\text { Individual smokes cigarettes, pipes, or } \\
\text { cigars }\end{array}$ & 0.3739 & 0.4838 & 36,356 \\
\hline Number Cigarettes & $\begin{array}{l}\text { If Individual smokes cigarettes, how many } \\
\text { cigarettes per day on average }\end{array}$ & 16.33 & 9.01 & 8,742 \\
\hline Drinker & $\begin{array}{l}\text { Individual reports that she often and regu- } \\
\text { larly drinks beer, wine, liquor, or alcoholic } \\
\text { mixed drinks }\end{array}$ & 0.1607 & 41.99 & 12,465 \\
\hline Hours (Actual) & Usual weekly hours worked & 44.79 & 9.80 & 35,232 \\
\hline Hours (Contract) & $\begin{array}{l}\text { Weekly hours specified by individual's la- } \\
\text { bor contract }\end{array}$ & 38.57 & 4.33 & 28,659 \\
\hline Hours (Overtime) & Usual weekly hours of overtime & 3.03 & 4.18 & 30,521 \\
\hline
\end{tabular}

Note: Only individuals older than 25 years living in households with children that receive child benefit are included. Summary statistics on the number of cigarettes are conditional on smoking any cigarettes at all. The statistics for labor supply variables incluse only males who are in the labor force and currently employed. 
Table 3: Household Level: Housing

\begin{tabular}{|c|c|c|c|c|}
\hline & $\begin{array}{c}(1) \\
\mathrm{P}(\text { Renting })\end{array}$ & $\begin{array}{c}(2) \\
\ln \text { Size }\left(m^{2}\right)\end{array}$ & $\begin{array}{c}(3) \\
\ln \text { Size (Rooms) }\end{array}$ & $\begin{array}{c}(4) \\
\text { Yard }\end{array}$ \\
\hline $\ln ($ Kindergeld $)$ & $\begin{array}{c}-0.0694^{* *} \\
(0.0273)\end{array}$ & $\begin{array}{c}0.0565^{* * *} \\
(0.0211)\end{array}$ & $\begin{array}{l}0.0643^{* * *} \\
(0.0215)\end{array}$ & $\begin{array}{l}0.0676^{* *} \\
(0.0286)\end{array}$ \\
\hline $\ln (\mathrm{HH}$ Income $)$ & $\begin{array}{c}-0.0649^{* * *} \\
(0.0075)\end{array}$ & $\begin{array}{c}0.0419^{* * *} \\
(0.0055)\end{array}$ & $\begin{array}{l}0.0436^{* * *} \\
(0.0056)\end{array}$ & $\begin{array}{l}0.0147^{* *} \\
(0.0071)\end{array}$ \\
\hline Number of Children & $\begin{array}{l}-0.0080 \\
(0.0154)\end{array}$ & $\begin{array}{l}0.0204^{*} \\
(0.0124)\end{array}$ & $\begin{array}{l}0.0256^{* *} \\
(0.0123)\end{array}$ & $\begin{array}{l}-0.0054 \\
(0.0161)\end{array}$ \\
\hline Single Parent & $\begin{array}{l}0.0903^{* * *} \\
(0.0145)\end{array}$ & $\begin{array}{c}-0.1105^{* * *} \\
(0.0106)\end{array}$ & $\begin{array}{c}-0.0971^{* * *} \\
(0.0100)\end{array}$ & $\begin{array}{c}-0.0572^{* * *} \\
(0.0155)\end{array}$ \\
\hline Children age $<16$ & $\begin{array}{c}-0.0454^{* * *} \\
(0.0079)\end{array}$ & $\begin{array}{c}0.0333^{* * *} \\
(0.0058)\end{array}$ & $\begin{array}{l}0.0449^{* * *} \\
(0.0059)\end{array}$ & $\begin{array}{l}-0.0043 \\
(0.0087)\end{array}$ \\
\hline Children ages $<16 \&>16$ & $\begin{array}{c}-0.0285^{* * *} \\
(0.0071)\end{array}$ & $\begin{array}{c}0.0298^{* * *} \\
(0.0052)\end{array}$ & $\begin{array}{c}0.0426^{* * *} \\
(0.0057)\end{array}$ & $\begin{array}{l}-0.0010 \\
(0.0075)\end{array}$ \\
\hline Foreign Head of HH & $\begin{array}{c}0.0347 \\
(0.0310)\end{array}$ & $\begin{array}{l}-0.0356^{*} \\
(0.0187)\end{array}$ & $\begin{array}{l}-0.0345^{*} \\
(0.0187)\end{array}$ & $\begin{array}{l}-0.0257 \\
(0.0334)\end{array}$ \\
\hline Main Tenant & & $\begin{array}{c}-0.2461^{* * *} \\
(0.0108)\end{array}$ & $\begin{array}{c}-0.2192^{* * *} \\
(0.0105)\end{array}$ & $\begin{array}{c}-0.2486^{* * *} \\
(0.0158)\end{array}$ \\
\hline Sublessee & & $\begin{array}{c}-0.2620^{* * *} \\
(0.0275)\end{array}$ & $\begin{array}{c}-0.2524^{* * *} \\
(0.0257)\end{array}$ & $\begin{array}{c}-0.1735^{* * *} \\
(0.0258)\end{array}$ \\
\hline Household Fixed Effects & Yes & Yes & Yes & Yes \\
\hline $\mathrm{p}(\alpha=\beta)$ & 0.8762 & 0.5085 & 0.3562 & 0.0747 \\
\hline Mean of Dependent Variable & 0.4704 & 4.6451 & 1.4464 & 0.7005 \\
\hline Observations & 39765 & 39765 & 39765 & 39210 \\
\hline
\end{tabular}

Standard errors clustered at the household level are in parenthesis. ${ }^{*} p<0.1,{ }^{* *} p<0.05,{ }^{* * *} p<0.01$. All regressions include household fixed effects. All regressions include regional dummies and region-specific time trends. Household income does not include the Child Benefit. Both Child Benefit and Household Income are Measured in Real $2005 €$ 
Table 4: Household Level: Housing (Renters)

\begin{tabular}{lccccc}
\hline & $(1)$ & $(2)$ & $(3)$ & $(4)$ & $(5)$ \\
& $\ln$ Rent $/ m^{2}$ & ln Utililties & ln Size $\left(m^{2}\right)$ & ln Size (Rooms) & Yard \\
\hline $\ln ($ Kindergeld) & -0.0234 & 0.0437 & $0.0749^{* *}$ & $0.1056^{* * *}$ & 0.0375 \\
& $(0.0328)$ & $(0.0394)$ & $(0.0295)$ & $(0.0274)$ & $(0.0533)$ \\
$\ln ($ HH Income) & $0.0197^{* *}$ & -0.0088 & $0.0551^{* * *}$ & $0.0517^{* * *}$ & 0.0140 \\
& $(0.0093)$ & $(0.0114)$ & $(0.0066)$ & $(0.0073)$ & $(0.0118)$ \\
Number of Children & 0.0068 & -0.0266 & 0.0177 & 0.0097 & 0.0177 \\
& $(0.0189)$ & $(0.0229)$ & $(0.0176)$ & $(0.0155)$ & $(0.0303)$ \\
Single Parent & $0.0287^{*}$ & 0.0128 & $-0.1119^{* * *}$ & $-0.0948^{* * *}$ & $-0.0540^{* * *}$ \\
& $(0.0151)$ & $(0.0170)$ & $(0.0122)$ & $(0.0115)$ & $(0.0208)$ \\
Children age $<16$ & $-0.0210^{* *}$ & $-0.0308^{* *}$ & $0.0348^{* * *}$ & $0.0424^{* * *}$ & -0.0076 \\
& $(0.0101)$ & $(0.0143)$ & $(0.0077)$ & $(0.0078)$ & $(0.0156)$ \\
Children ages $<16 \&>16$ & -0.0069 & -0.0159 & $0.0285^{* * *}$ & $0.0407^{* * *}$ & -0.0009 \\
& $(0.0103)$ & $(0.0134)$ & $(0.0075)$ & $(0.0078)$ & $(0.0158)$ \\
Foreign Head of HH & -0.0237 & $-0.0646^{*}$ & -0.0098 & -0.0333 & 0.0039 \\
& $(0.0244)$ & $(0.0346)$ & $(0.0200)$ & $(0.0214)$ & $(0.0431)$ \\
\hline Mean of Dependent Variable & 1.7038 & 0.5885 & 4.4405 & 1.2606 & 0.4434 \\
Household Fixed Effects & Yes & Yes & Yes & Yes & Yes \\
Observations & 0.2079 & 0.2140 & 0.5137 & 0.0592 & 0.6702 \\
\hline Standar & 17864 & 17864 & 18704 & 18704 & 18326 \\
\hline
\end{tabular}

Standard errors clustered at the household level are in parenthesis. ${ }^{*} p<0.1,{ }^{* *} p<0.05,{ }^{* * *} p<0.01$. All regressions include household fixed effects. All regressions include regional dummies and region-specific time trends. Household income does not include the Child Benefit. Both Child Benefit and Household Income are Measured in Real $2005 €$ 
Table 5: Household Level: Housing (Owners)

\begin{tabular}{|c|c|c|c|}
\hline & $\begin{array}{c}(1) \\
\ln \text { Size }\left(m^{2}\right)\end{array}$ & $\begin{array}{c}(2) \\
\ln \text { Size (Rooms) }\end{array}$ & $\begin{array}{c}(3) \\
\text { Yard }\end{array}$ \\
\hline $\ln ($ Kindergeld $)$ & $\begin{array}{c}0.0254 \\
(0.0271)\end{array}$ & $\begin{array}{c}0.0209 \\
(0.0282)\end{array}$ & $\begin{array}{c}0.0342^{*} \\
(0.0200)\end{array}$ \\
\hline $\ln (\mathrm{HH}$ Income $)$ & $\begin{array}{c}0.0237^{* * *} \\
(0.0077)\end{array}$ & $\begin{array}{c}0.0271^{* * *} \\
(0.0074)\end{array}$ & $\begin{array}{l}0.0120^{* *} \\
(0.0058)\end{array}$ \\
\hline Number of Children & $\begin{array}{c}0.0139 \\
(0.0156)\end{array}$ & $\begin{array}{c}0.0238 \\
(0.0158)\end{array}$ & $\begin{array}{l}-0.0039 \\
(0.0107)\end{array}$ \\
\hline Single Parent & $\begin{array}{c}-0.0599^{* * *} \\
(0.0166)\end{array}$ & $\begin{array}{c}-0.0387^{* *} \\
(0.0154)\end{array}$ & $\begin{array}{l}-0.0229 \\
(0.0154)\end{array}$ \\
\hline Children age $<16$ & $\begin{array}{c}0.0274^{* * *} \\
(0.0076)\end{array}$ & $\begin{array}{c}0.0352^{* * *} \\
(0.0082)\end{array}$ & $\begin{array}{l}-0.0016 \\
(0.0073)\end{array}$ \\
\hline Children ages $<16 \&>16$ & $\begin{array}{c}0.0263^{* * *} \\
(0.0067)\end{array}$ & $\begin{array}{c}0.0382^{* * *} \\
(0.0078)\end{array}$ & $\begin{array}{c}0.0013 \\
(0.0061)\end{array}$ \\
\hline Foreign Head of $\mathrm{HH}$ & $\begin{array}{c}-0.0946^{* * *} \\
(0.0360)\end{array}$ & $\begin{array}{c}-0.0731^{* *} \\
(0.0346)\end{array}$ & $\begin{array}{c}-0.1042^{* *} \\
(0.0530)\end{array}$ \\
\hline Mean of Dependent Variable & 4.8267 & 1.6113 & 0.9261 \\
\hline Household Fixed Effects & Yes & Yes & Yes \\
\hline $\mathrm{p}(\alpha=\beta)$ & 0.9540 & 0.8319 & 0.2963 \\
\hline Observations & 21061 & 21061 & 20884 \\
\hline
\end{tabular}


Table 6: Household Level: Car Ownership

\begin{tabular}{lccc}
\hline & \multicolumn{3}{c}{ Household has a Car } \\
\cline { 2 - 4 } & $(1)$ & $(2)$ & $(3)$ \\
& Entire Sammple & Low Income & Higher Income \\
\hline $\ln ($ Kindergeld $)$ & $0.0277^{* *}$ & 0.1356 & 0.0185 \\
& $(0.0136)$ & $(0.0970)$ & $(0.0118)$ \\
$\ln ($ HH Income $)$ & $0.0571^{* * *}$ & $0.1144^{* * *}$ & $0.0422^{* * *}$ \\
& $(0.0064)$ & $(0.0195)$ & $(0.0063)$ \\
Number of Children & -0.0073 & -0.0245 & -0.0080 \\
& $(0.0083)$ & $(0.0593)$ & $(0.0073)$ \\
Single Parent & $-0.1681^{* * *}$ & $-0.2007^{* * *}$ & $-0.1604^{* * *}$ \\
& $(0.0161)$ & $(0.0342)$ & $(0.0179)$ \\
Children age $<16$ & 0.0048 & 0.0060 & 0.0049 \\
& $(0.0061)$ & $(0.0289)$ & $(0.0056)$ \\
Children ages $<16 \&>16$ & 0.0011 & -0.0212 & 0.0026 \\
& $(0.0054)$ & $(0.0318)$ & $(0.0051)$ \\
Foreign Head of HH & 0.0302 & -0.0091 & $0.0406^{*}$ \\
& $(0.0263)$ & $(0.1038)$ & $(0.0232)$ \\
\hline Mean of Dependent Variable & 0.9129 & 0.5753 & 0.9575 \\
Household Fixed Effects & Yes & Yes & Yes \\
$\mathrm{p}(\alpha=\beta)$ & 0.0603 & 0.8353 & 0.0832 \\
Observations & 32734 & 3824 & 28910 \\
\hline Standard errors clustered at the household level are in & parenthesis. ${ }^{*} p<0.1{ }^{* *} p<$ \\
0.05, ${ }^{* * *} p<0.01$. All regressions include household fixed effects. All regressions include \\
regional dummies and region-specific time trends. Household income does not include the \\
Child Benefit. Both Child Benefit and Household Income are Measured in Real 2005€
\end{tabular}


Table 7: Household Level: Monthly Per Person Food Expenditures

\begin{tabular}{lccc}
\hline & \multicolumn{3}{c}{ Log of Per Capital Read Food Expenditure } \\
\cline { 2 - 4 } & $(1)$ & $(2)$ & $(3)$ \\
& Entire Sample & Low Income & Higher Income \\
\hline $\ln ($ Kindergeld $)$ & $0.1911^{* * *}$ & $0.3938^{* * *}$ & $0.1684^{* * *}$ \\
& $(0.0314)$ & $(0.1257)$ & $(0.0324)$ \\
$\ln ($ HH Income $)$ & $0.1764^{* * *}$ & $0.1837^{* * *}$ & $0.1715^{* * *}$ \\
& $(0.0139)$ & $(0.0399)$ & $(0.0147)$ \\
Number of Children & 0.0171 & -0.0375 & 0.0222 \\
& $(0.0188)$ & $(0.0758)$ & $(0.0194)$ \\
Single Parent & $-0.2253^{* * *}$ & $-0.2317^{* * *}$ & $-0.2233^{* * *}$ \\
& $(0.0219)$ & $(0.0511)$ & $(0.0243)$ \\
Children age $<16$ & 0.0207 & 0.0113 & $0.0277^{* *}$ \\
& $(0.0130)$ & $(0.0431)$ & $(0.0137)$ \\
Children ages $<16$ \& $>16$ & $0.0415^{* * *}$ & 0.0409 & $0.0460^{* * *}$ \\
& $(0.0123)$ & $(0.0478)$ & $(0.0127)$ \\
Foreign Head of HH & 0.0107 & 0.0602 & 0.0084 \\
& $(0.0413)$ & $(0.1040)$ & $(0.0451)$ \\
\hline Mean of Dependent Variable & 6.1551 & 5.7772 & 6.2023 \\
Household Fixed Effects & Yes & Yes & Yes \\
p $\alpha=\beta)$ & 0.6829 & 0.1218 & 0.9352 \\
Observations & 19848 & 2206 & 17642 \\
\hline Standard errors clustered at the household level are in parenthesis. & ${ }^{*} p<0.1,{ }^{* *} p<$ \\
$0.05, * * * p<0.01$. All regressions include household fixed effects. All regressions include \\
regional dummies and region-specific time trends. Household income does not include the \\
Child Benefit. Both Child Benefit and Household Income are Measured in Real $2005 €$
\end{tabular}


Table 8: Individual Level: Smoking

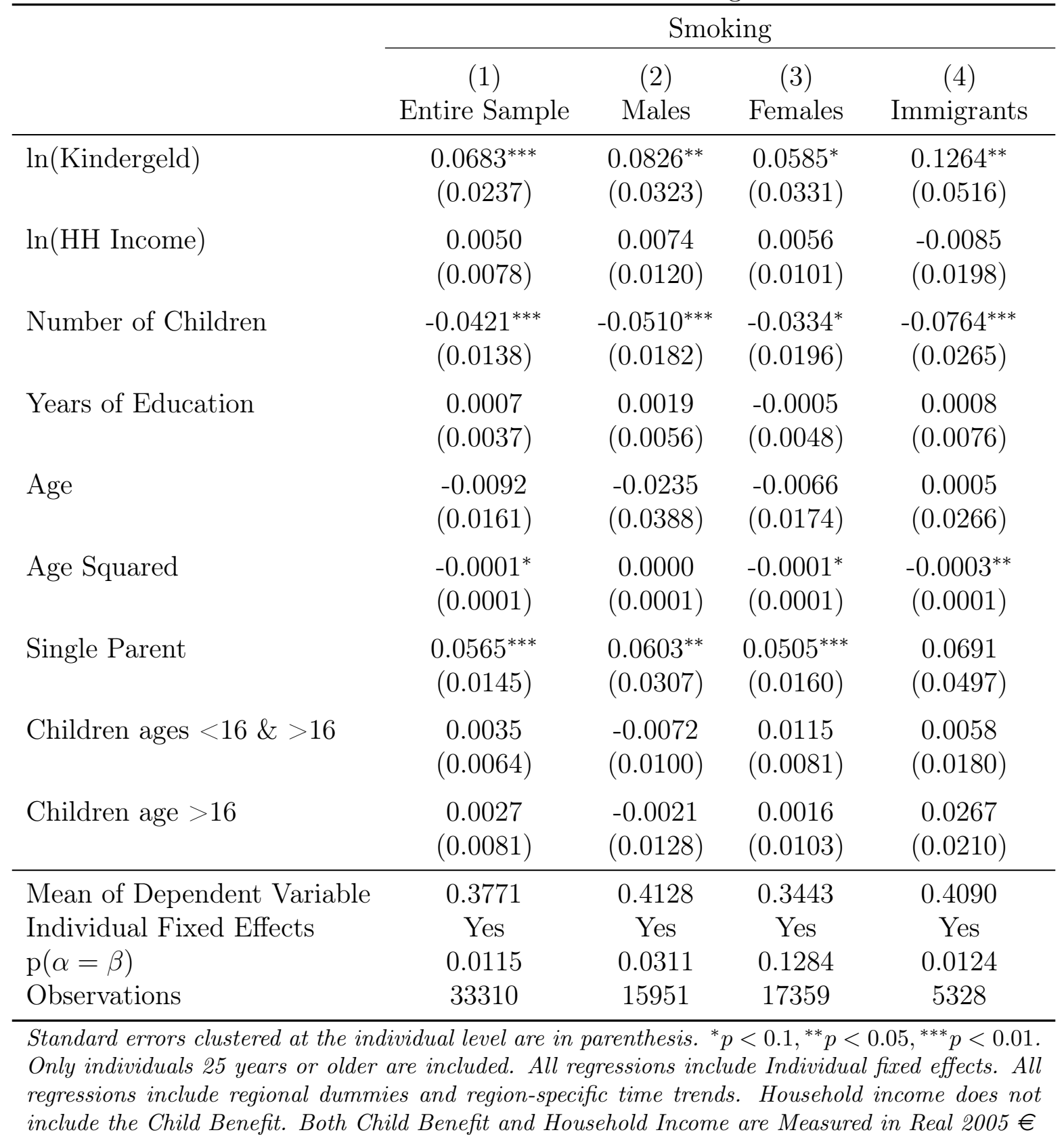


Table 9: Individual Level: Average Daily Number of Cigarettes Smoked

\begin{tabular}{lcccc}
\hline & \multicolumn{3}{c}{ Average Number of Cigarettes per Day } \\
\cline { 2 - 5 } & $(1)$ & $(2)$ & $(3)$ & $(4)$ \\
& Entire Sample & Males & Females & Immigrants \\
\hline $\ln ($ Kindergeld $)$ & -1.0817 & -0.4229 & -2.0006 & -3.9016 \\
& $(1.7604)$ & $(2.8756)$ & $(1.8407)$ & $(3.0050)$ \\
$\ln ($ HH Income $)$ & 0.0940 & 0.0943 & 0.0709 & 0.6664 \\
& $(0.3178)$ & $(0.5807)$ & $(0.3655)$ & $(0.8831)$ \\
Number of Children & 0.6608 & 0.3152 & 1.2881 & $2.5761^{*}$ \\
& $(1.0707)$ & $(1.7435)$ & $(1.1166)$ & $(1.4349)$ \\
Years of Education & -0.1632 & -0.0669 & -0.2609 & -0.2539 \\
& $(0.2531)$ & $(0.3517)$ & $(0.3199)$ & $(1.9551)$ \\
Age & -0.1839 & $4.0624^{* * *}$ & -0.5223 & -0.5991 \\
& $(0.6669)$ & $(0.3883)$ & $(0.5840)$ & $(0.6408)$ \\
Age Squared & $-0.0042^{*}$ & -0.0038 & -0.0028 & 0.0011 \\
& $(0.0023)$ & $(0.0033)$ & $(0.0033)$ & $(0.0058)$ \\
Single Parent & $1.8591^{* * *}$ & $3.1532^{* *}$ & $1.4700^{* * *}$ & 1.6725 \\
& $(0.4658)$ & $(1.5030)$ & $(0.4788)$ & $(1.1423)$ \\
Children ages $<16$ \& $>16$ & 0.1871 & 0.1649 & 0.1270 & 0.4621 \\
& $(0.2560)$ & $(0.4268)$ & $(0.3001)$ & $(0.6873)$ \\
Children age $>16$ & 0.1341 & -0.4303 & 0.4142 & -1.2177 \\
& $(0.3179)$ & $(0.5291)$ & $(0.3969)$ & $(0.9416)$ \\
\hline Mean of Dependent Variable & 16.2824 & 18.1899 & 14.3862 & 17.0867 \\
Individual Fixed Effects & Yes & Yes & Yes & Yes \\
p $(\alpha=\beta)$ & 0.5112 & 0.8613 & 0.2633 & 0.1362 \\
Observations & 8102 & 4039 & 4063 & 1350 \\
\hline Sta & & &
\end{tabular}

Standard errors clustered at the individual level are in parenthesis. ${ }^{*} p<0.1,{ }^{* *} p<0.05,{ }^{* * *} p<0.01$. Only individuals 25 years or older are included. All regressions include Individual fixed effects. All regressions include regional dummies and region-specific time trends. Household income does not include the Child Benefit. Both Child Benefit and Household Income are Measured in Real $2005 €$ 
Table 10: Individual Level: Smoking

\begin{tabular}{|c|c|c|c|c|c|c|}
\hline & \multicolumn{6}{|c|}{ Smoking } \\
\hline & \multicolumn{3}{|c|}{ Low Income } & \multicolumn{3}{|c|}{ Higer Income } \\
\hline & $\begin{array}{l}\text { (1) } \\
\text { All }\end{array}$ & $\begin{array}{c}(2) \\
\text { Males }\end{array}$ & $\begin{array}{c}(3) \\
\text { Females }\end{array}$ & $\begin{array}{l}\text { (4) } \\
\text { All }\end{array}$ & $\begin{array}{c}(5) \\
\text { Males }\end{array}$ & $\begin{array}{c}(6) \\
\text { Females }\end{array}$ \\
\hline $\ln ($ Kindergeld $)$ & $\begin{array}{c}-0.0198 \\
(0.0961)\end{array}$ & $\begin{array}{c}0.2022 \\
(0.1802)\end{array}$ & $\begin{array}{l}-0.0486 \\
(0.0964)\end{array}$ & $\begin{array}{c}0.0903^{* * *} \\
(0.0241)\end{array}$ & $\begin{array}{c}0.0903^{* * *} \\
(0.0344)\end{array}$ & $\begin{array}{c}0.0908^{* * *} \\
(0.0333)\end{array}$ \\
\hline $\ln ($ HH Income $)$ & $\begin{array}{c}-0.0203 \\
(0.0293)\end{array}$ & $\begin{array}{c}-0.0307 \\
(0.0559)\end{array}$ & $\begin{array}{l}-0.0135 \\
(0.0343)\end{array}$ & $\begin{array}{c}0.0140 \\
(0.0100)\end{array}$ & $\begin{array}{c}0.0244 \\
(0.0149)\end{array}$ & $\begin{array}{c}0.0062 \\
(0.0132)\end{array}$ \\
\hline Number of Children & $\begin{array}{c}0.0246 \\
(0.0558)\end{array}$ & $\begin{array}{c}-0.1196 \\
(0.0984)\end{array}$ & $\begin{array}{c}0.0473 \\
(0.0529)\end{array}$ & $\begin{array}{c}-0.0567^{* * *} \\
(0.0142)\end{array}$ & $\begin{array}{c}-0.0567^{* * *} \\
(0.0200)\end{array}$ & $\begin{array}{c}-0.0545^{* * *} \\
(0.0197)\end{array}$ \\
\hline Years of Education & $\begin{array}{c}0.0291^{* *} \\
(0.0136)\end{array}$ & $\begin{array}{c}0.0654^{* *} \\
(0.0294)\end{array}$ & $\begin{array}{c}0.0138 \\
(0.0144)\end{array}$ & $\begin{array}{l}-0.0005 \\
(0.0041)\end{array}$ & $\begin{array}{c}0.0031 \\
(0.0060)\end{array}$ & $\begin{array}{l}-0.0040 \\
(0.0054)\end{array}$ \\
\hline Age & $\begin{array}{c}-0.0349 \\
(0.0260)\end{array}$ & $\begin{array}{c}-0.0239 \\
(0.0220)\end{array}$ & $\begin{array}{l}-0.0538 \\
(0.0396)\end{array}$ & $\begin{array}{c}0.0060 \\
(0.0131)\end{array}$ & $\begin{array}{l}-0.0330 \\
(0.0659)\end{array}$ & $\begin{array}{l}0.0134^{*} \\
(0.0077)\end{array}$ \\
\hline Age Squared & $\begin{array}{c}-0.0000 \\
(0.0001)\end{array}$ & $\begin{array}{c}0.0001 \\
(0.0003)\end{array}$ & $\begin{array}{l}-0.0001 \\
(0.0002)\end{array}$ & $\begin{array}{c}-0.0001^{*} \\
(0.0001)\end{array}$ & $\begin{array}{c}0.0000 \\
(0.0001)\end{array}$ & $\begin{array}{c}-0.0001^{*} \\
(0.0001)\end{array}$ \\
\hline Single Parent & $\begin{array}{l}0.0760^{* *} \\
(0.0338)\end{array}$ & $\begin{array}{c}0.0323 \\
(0.0386)\end{array}$ & $\begin{array}{l}0.0806^{* *} \\
(0.0369)\end{array}$ & $\begin{array}{c}0.0674^{* * *} \\
(0.0209)\end{array}$ & $\begin{array}{l}0.0879^{* *} \\
(0.0423)\end{array}$ & $\begin{array}{l}0.0531^{* *} \\
(0.0239)\end{array}$ \\
\hline Children ages $<16 \&>16$ & $\begin{array}{l}0.0521^{* *} \\
(0.0257)\end{array}$ & $\begin{array}{l}0.1061^{*} \\
(0.0585)\end{array}$ & $\begin{array}{c}0.0295 \\
(0.0273)\end{array}$ & $\begin{array}{l}-0.0017 \\
(0.0068)\end{array}$ & $\begin{array}{l}-0.0138 \\
(0.0104)\end{array}$ & $\begin{array}{c}0.0083 \\
(0.0088)\end{array}$ \\
\hline Children age $>16$ & $\begin{array}{c}0.0240 \\
(0.0280)\end{array}$ & $\begin{array}{c}0.0790 \\
(0.0611)\end{array}$ & $\begin{array}{c}0.0028 \\
(0.0310) \\
\end{array}$ & $\begin{array}{l}-0.0027 \\
(0.0088)\end{array}$ & $\begin{array}{c}-0.0097 \\
(0.0136) \\
\end{array}$ & $\begin{array}{l}-0.0013 \\
(0.0112) \\
\end{array}$ \\
\hline $\begin{array}{l}\text { Mean of Dependent Vari- } \\
\text { able }\end{array}$ & 0.5363 & 0.5695 & 0.5195 & 0.3564 & 0.3991 & 0.3143 \\
\hline Individual Fixed Effects & Yes & $\mathrm{Ye}$ & $\mathrm{Ye}$ & Yes & Yes & Yes \\
\hline & 0.9956 & 0.2551 & 0.7266 & 0.0039 & 0.0794 & 0.0215 \\
\hline Observations & 3830 & 1287 & 2543 & 29480 & 14664 & 14816 \\
\hline
\end{tabular}

Standard errors clustered at the individual level are in parenthesis. ${ }^{*} p<0.1,{ }^{* *} p<0.05,{ }^{* * *} p<0.01$. Only individuals 25 years or older are included. All regressions include Individual fixed effects. All regressions include regional dummies and region-specific time trends. Household income does not include the Child Benefit. Both Child Benefit and Household Income are Measured in Real $2005 €$ 
Table 11: Individual Level: Drinking Alcohol

\begin{tabular}{|c|c|c|c|}
\hline & \multicolumn{3}{|c|}{ Regularly Drinks Alcohol } \\
\hline & $\begin{array}{c}(1) \\
\text { Entire Sample }\end{array}$ & $\begin{array}{c}(2) \\
\text { Males }\end{array}$ & $\begin{array}{c}(3) \\
\text { Females }\end{array}$ \\
\hline $\ln ($ Kindergeld $)$ & $\begin{array}{l}-0.0145 \\
(0.0815)\end{array}$ & $\begin{array}{l}-0.0977 \\
(0.1314)\end{array}$ & $\begin{array}{c}0.0649 \\
(0.0962)\end{array}$ \\
\hline $\ln (\mathrm{HH}$ Income $)$ & $\begin{array}{c}0.0251 \\
(0.0178)\end{array}$ & $\begin{array}{c}0.0092 \\
(0.0356)\end{array}$ & $\begin{array}{l}0.0359^{* *} \\
(0.0178)\end{array}$ \\
\hline Number of Children & $\begin{array}{c}0.0068 \\
(0.0482)\end{array}$ & $\begin{array}{c}0.0599 \\
(0.0764)\end{array}$ & $\begin{array}{l}-0.0436 \\
(0.0585)\end{array}$ \\
\hline Years of Education & $\begin{array}{l}-0.0057 \\
(0.0182)\end{array}$ & $\begin{array}{l}-0.0324 \\
(0.0303)\end{array}$ & $\begin{array}{c}0.0227 \\
(0.0200)\end{array}$ \\
\hline Age & $\begin{array}{c}0.0053 \\
(0.0139)\end{array}$ & $\begin{array}{c}0.0202 \\
(0.0268)\end{array}$ & $\begin{array}{c}0.0060 \\
(0.0153)\end{array}$ \\
\hline Age Squared & $\begin{array}{l}-0.0000 \\
(0.0002)\end{array}$ & $\begin{array}{l}-0.0001 \\
(0.0003)\end{array}$ & $\begin{array}{c}0.0000 \\
(0.0002)\end{array}$ \\
\hline Single Parent & $\begin{array}{c}0.0155 \\
(0.0308)\end{array}$ & $\begin{array}{c}0.1148 \\
(0.1147)\end{array}$ & $\begin{array}{c}0.0131 \\
(0.0314)\end{array}$ \\
\hline Children ages $<16 \&>16$ & $\begin{array}{l}-0.0277^{*} \\
(0.0151)\end{array}$ & $\begin{array}{l}-0.0341 \\
(0.0253)\end{array}$ & $\begin{array}{l}-0.0210 \\
(0.0178)\end{array}$ \\
\hline Children age $>16$ & $\begin{array}{l}-0.0154 \\
(0.0209)\end{array}$ & $\begin{array}{l}-0.0170 \\
(0.0369)\end{array}$ & $\begin{array}{l}-0.0123 \\
(0.0232)\end{array}$ \\
\hline Mean of Dependent Variable & 0.1643 & 0.2600 & 0.0810 \\
\hline Individual Fixed Effects & Yes & Yes & Yes \\
\hline $\mathrm{p}(\alpha=\beta)$ & 0.6307 & 0.4294 & 0.7623 \\
\hline Observations & 11489 & 5350 & 6139 \\
\hline
\end{tabular}


Table 12: Individual Level: Labour Supply of Males

\begin{tabular}{|c|c|c|c|}
\hline & $\begin{array}{c}(1) \\
\ln \text { Hours (Actual) }\end{array}$ & $\begin{array}{c}(2) \\
\ln \text { Hours (Contract) }\end{array}$ & $\begin{array}{c}(3) \\
\ln \text { Hours (Overtime) }\end{array}$ \\
\hline $\ln ($ Kindergeld $)$ & $\begin{array}{c}-0.0275^{* *} \\
(0.0114)\end{array}$ & $\begin{array}{c}-0.0126^{* *} \\
(0.0061)\end{array}$ & $\begin{array}{c}-0.1349^{* *} \\
(0.0603)\end{array}$ \\
\hline $\ln (\mathrm{HH}$ Income $)$ & $\begin{array}{c}0.0384^{* * *} \\
(0.0081)\end{array}$ & $\begin{array}{l}0.0141^{* *} \\
(0.0060)\end{array}$ & $\begin{array}{c}0.1431^{* * *} \\
(0.0365)\end{array}$ \\
\hline Number of Children & $\begin{array}{l}0.0116^{*} \\
(0.0068)\end{array}$ & $\begin{array}{c}0.0015 \\
(0.0037)\end{array}$ & $\begin{array}{c}0.0557^{*} \\
(0.0333)\end{array}$ \\
\hline Years of Education & $\begin{array}{c}0.0134^{* * *} \\
(0.0038)\end{array}$ & $\begin{array}{l}0.0058^{*} \\
(0.0030)\end{array}$ & $\begin{array}{c}0.0185 \\
(0.0125)\end{array}$ \\
\hline Age & $\begin{array}{l}0.0203^{* *} \\
(0.0097)\end{array}$ & $\begin{array}{l}0.0086^{*} \\
(0.0051)\end{array}$ & $\begin{array}{c}0.1360^{* * *} \\
(0.0452)\end{array}$ \\
\hline Age Squared & $\begin{array}{c}-0.0002^{* * *} \\
(0.0000)\end{array}$ & $\begin{array}{l}-0.0000 \\
(0.0000)\end{array}$ & $\begin{array}{c}-0.0005^{* *} \\
(0.0002)\end{array}$ \\
\hline Tenure & $\begin{array}{c}-0.0012^{* *} \\
(0.0006)\end{array}$ & $\begin{array}{l}-0.0003 \\
(0.0003)\end{array}$ & $\begin{array}{c}-0.0059^{* *} \\
(0.0027)\end{array}$ \\
\hline FT-Work Experience & $\begin{array}{c}0.0018 \\
(0.0057)\end{array}$ & $\begin{array}{c}0.0008 \\
(0.0047)\end{array}$ & $\begin{array}{c}0.0054 \\
(0.0207)\end{array}$ \\
\hline Single Parent & $\begin{array}{l}-0.0283 \\
(0.0208)\end{array}$ & $\begin{array}{l}-0.0202 \\
(0.0223)\end{array}$ & $\begin{array}{l}-0.0784 \\
(0.0765)\end{array}$ \\
\hline Children ages $<16 \&>16$ & $\begin{array}{l}-0.0010 \\
(0.0046)\end{array}$ & $\begin{array}{l}-0.0002 \\
(0.0028)\end{array}$ & $\begin{array}{l}-0.0076 \\
(0.0233)\end{array}$ \\
\hline Children age $>16$ & $\begin{array}{l}-0.0023 \\
(0.0063)\end{array}$ & $\begin{array}{l}-0.0057 \\
(0.0042)\end{array}$ & $\begin{array}{l}-0.0309 \\
(0.0299)\end{array}$ \\
\hline Part-Time & $\begin{array}{c}-0.4319^{* * *} \\
(0.0288)\end{array}$ & $\begin{array}{c}-0.3907^{* * *} \\
(0.0298)\end{array}$ & $\begin{array}{l}-0.1589 \\
(0.1020)\end{array}$ \\
\hline Irregularly Employed & $\begin{array}{c}-0.9266^{* * *} \\
(0.0585)\end{array}$ & $\begin{array}{c}-0.7372^{* * *} \\
(0.0817)\end{array}$ & $\begin{array}{c}0.1962 \\
(0.2437)\end{array}$ \\
\hline Civil Servant & $\begin{array}{c}-0.0176^{*} \\
(0.0098)\end{array}$ & $\begin{array}{c}0.0027 \\
(0.0056)\end{array}$ & $\begin{array}{c}-0.0304 \\
(0.0393)\end{array}$ \\
\hline Mean of Dependent Variable & 3.7765 & 3.6454 & 13260 \\
\hline Individual Fixed Effects & Yes & Yes & Yes \\
\hline $\mathrm{p}(\alpha=\beta)$ & 0.0000 & 0.0016 & 0.0001 \\
\hline Observations & 31397 & 25793 & 16304 \\
\hline
\end{tabular}

Standard errors clustered at the individual level are in parenthesis. ${ }^{*} p<0.1,{ }^{* *} p<0.05,{ }^{* * *} p<0.01$. Only individuals 25 years or older are included. All regressions include Individual fixed effects. All regressions include regional dummies and region-specific time trends. Household income does not include the Child Benefit. Both Child Benefit and Household Income are Measured in Real $2005 €$ 